\title{
STUDY OF CHROMIUM DESORPTION FROM POLLUTED SOIL AROUND TANNERY INDUSTRY: EFFECT OF LOW MOLECULAR WEIGHT ORGANIC ACID (LMWOA)
}

\author{
Suherman $^{1, *}$, Anis Kholifatur Rosyidah ${ }^{1}$, Adhitasari Suratman ${ }^{1}$, Nurul \\ Hidayat Aprilita $^{1}$, Mudasir ${ }^{1}$ and Kinichi Morita ${ }^{2}$ \\ ${ }^{1}$ Department of Chemistry, Universitas Gadjah Mada, Sekip Utara Kotak Pos 21 BLS \\ Yogyakarta-55281, Indonesia \\ ${ }^{2}$ New Business Development Office, Corporate R\&D Division, Ushio INC. 1-6-5 Marunouchi, \\ Chiyoda-ku, Tokyo 100-8150, Japan. \\ *E-mail: suherman.mipa@ugm.ac.id
}

\begin{abstract}
The effect of low-molecular-weight organic acids (LMWOA) on desorption of chromium in soil contaminated with leather tanning industry waste water has been conducted. The aims of this research are to analyze the soil contamination around industry area, to study the physicochemical soil properties, and to investigate the effect of low molecular weight organic acids (citric acid, tartaric acid, and oxalic acid) on chromium desorption from the soil. The soil samples used in this study were collected from two different distances from the waste water sources. These soil samples were analyzed by X-ray diffraction spectroscopy (XRD) and Fourier-transform infrared spectroscopy (FTIR), and then determine their total organic compound, the content of chromium and cation exchange capacity (CEC). In the desorption part, the effect of LMWOA concentration, $\mathrm{pH}$ level and time variation were investigated and measured using atomic adsorption spectrophotometry (AAS) method.

The results showed that the soil samples 1 and 2 had the chromium content at 1,402 $\mathrm{mg} \mathrm{kg}^{-1}$ and $1,071 \mathrm{mg} \mathrm{kg}{ }^{-1}$, respectively. Soil sample 1 had a higher value of CEC and total organic carbon than soil sample 2 . In the chromium desorption process, there is a tendency of higher concentration of LMWOA desorbed the higher amount of chromium metal. The effective desorption occurred at the acid condition. For the kinetics study of metal desorption from soil samples in the presence of LMWOA, citric acid produced higher desorption rate constant (high k-value) than oxalic and tartaric acids.
\end{abstract}

Keywords: Tannery industry, Chromium, Desorption, Low Molecular Weight Organic Acids (LMWOA)

(c) RASĀYAN. All rights reserved

\section{INTRODUCTION}

The leather tannery industry is one of the industrial types that produce waste water with highly chromium contamination. This contamination derives from the use of chromium salt in the tanning process. The usage of chromium salt is not all absorbed by the animal skin in tannery processes, but also released along with waste water ${ }^{1,2}$. Thus, chromium can be accumulated in the soil by the time. The presence and accumulation of heavy metal in the soil can have adverse effects on the environment ${ }^{3}$.

According to Stevenson ${ }^{4}$, metal ions can bind to the organic matter in the soil through the formation of a complex compound. The metal-organic complex in this soil can move into the root zone through the cell membrane and then into the hair root ${ }^{5}$. The process of heavy metal accumulation in the soil can also occur due to the strong adsorption of clay colloid in the soil against heavy metals ${ }^{6}$.

An alternative solution to reduce the impact of heavy metal pollution in the soil is by using low molecular weight organic acid (LMWOA). This is due to the ability of these organic acids in desorption of heavy metals in the soil ${ }^{7}$. LMWOA has sail and complexity properties that can control heavy metal mobility in the soil. LMWOA is a natural compound derived from plant roots, microbial secretion and decomposition of plant and animal residues ${ }^{8}$.

Rasayan J. Chem., 12(3), 1279-1286(2019)

http://dx.doi.org/10.31788/RJC.2019.1235203

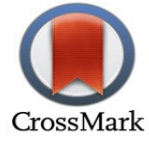


Among LMWOAs, citric acid, tartaric acid, and oxalic acid all demonstrate the ability to effectively separate heavy metals in soil. Yuan et al. ${ }^{7}$ showed that citric acid could increase desorption of $\mathrm{Cu}$ in the $\mathrm{pH}$ range of 2-10 and for the metallic Cd of citrate acid only increases the desorption capacity at $\mathrm{pH}$ less than 3. For oxalic acid, the desorption process in $\mathrm{Cu}$ and $\mathrm{Cd}$ increased at $\mathrm{pH}$ at 4.2 up to 6.4. Jalali and Taghipour ${ }^{9}$ concluded that the chromium desorption process in soil was the most effective using citric acid, subsequently oxalic acid and $\mathrm{CaCl}_{2}$. While Chiang et al. ${ }^{10}$ in the study of soil contaminated by $\mathrm{Cs}$ reported that the organic acids including citric acid, oxalic acid, and tartaric acid have the effective capability of removing heavy metals indicated by the high concentration of desorbed heavy metals.

Based on the above background, this research will study the characteristic of contaminated soil samples around the leather tanning industry, and investigation of chromium desorption process in soil samples with the presence of LMWOA. In addition, the kinetics model of desorption will also be evaluated.

\section{EXPERIMENTAL}

\section{Material and Methods}

Soil samples were taken from two different sampling points with a sampling depth of between $10-30 \mathrm{~cm}$. All sampling was collected 3 points each distance. The sample point 1 was taken at a location close to the industrial waste water outlet at Piyungan, Yogyakarta-Indonesia and sample point 2 was far from $50 \mathrm{~m}$ of the location of sample point 1 to evaluate the distance effect on the soil pollution. The materials used by pre-analysis qualities from Merck were barium chloride dihydrate $\left(\mathrm{BaCl}_{2} \cdot 2 \mathrm{H}_{2} \mathrm{O}\right)$, magnesium sulfate heptahydrate $\left(\mathrm{MgSO}_{4} \cdot 7 \mathrm{H}_{2} \mathrm{O}\right)$, standard solution of chromium $1,000 \mathrm{mg} / \mathrm{L}$, iron (II) ammonium sulphate (FAS, $\left.\mathrm{Fe}\left(\mathrm{NH}_{4}\right)_{2}\left(\mathrm{SO}_{4}\right)_{2} \cdot 6 \mathrm{H}_{2} \mathrm{O}\right)$, potassium dichromate $\left(\mathrm{K}_{2} \mathrm{Cr}_{2} \mathrm{O}_{7}\right)$, hydrofluoric acid (HF), sulfuric acid $\left(\mathrm{H}_{2} \mathrm{SO}_{4}\right)$, phosphoric acid $\left(\mathrm{H}_{3} \mathrm{PO}_{4}\right)$, indicator of ferroin $\left(\mathrm{C}_{36} \mathrm{H}_{24} \mathrm{FeN}_{6} \mathrm{O}_{4} \mathrm{~S}\right)$, tartaric acid, citric acid, oxalic acid, and Whatman 42 filter paper.

The equipment used in this research are glass and plastic containers, magnetic stirrer, porcelain cup, analytical balance (Mattler Toledo AB54-S), digital balance sheet (ACIS AD 300i), shaker (Marius Instrumenten), oven (Kirin), X-ray diffractometer (Shimadzu model XRD-6000) was used for soil mineral type analysis, Fourier transform infrared spectrometry (Hanna HI98103) for functional groups of soil samples identification, Hot plate-stirrer (Thermolyne Cimarec 1), a set of reflux device and an atomic absorption spectrophotometer (AAS, Perkin Elmer 3110) to calculate metal content in the samples.

\section{General procedure \\ Determination of Chromium Content in the Soil Samples}

The determination of chromium content is conducted based on the British Standards European Norm (BS EN) method $13656^{11}$. A total of $0.5 \mathrm{~g}$ of dry soil samples were extracted with the addition of $4 \mathrm{~mL}$ of $40 \%$ HF solution and shook for $24 \mathrm{~h}$. The mixture was added $12 \mathrm{~mL}$ of Aqua regia (a mixture of nitric acid and hydrochloric acid, in a molar ratio of 1:3) and shook back for $24 \mathrm{~h}$. The filtrate was separated which was further measured the chromium content with the AAS instrument. Data retrieval is repeated three times to calculate the standard deviation.

\section{Total Organic Compound (TOC) Determination}

A total of $0.5 \mathrm{~g}$ of dry soil samples were mixed with $5 \mathrm{~mL}$ of a $0.2 \mathrm{M} \mathrm{K}_{2} \mathrm{Cr}_{2} \mathrm{O}_{7}$ solution in a round bottom flask. The mixture was added with $15 \mathrm{~mL}$ of $\mathrm{H}_{2} \mathrm{SO}_{4}$ solution then refluxed for $30 \mathrm{~min}$ at $135{ }^{\circ} \mathrm{C}$. The obtained extraction was cooled and $5 \mathrm{ml}$ of $\mathrm{H}_{3} \mathrm{PO}_{4}$ was added and subsequently diluted to $100 \mathrm{~mL}$ volume. The extract solution was titrated with a $0.14 \mathrm{M}$ FAS solution with the addition of an earlier ferroin indicator. Data retrieval was repeated three times to calculate the standard deviation.

\section{Cation Exchange Capacity Determination}

The cation exchange capacity method is based on DIN ISO $11260^{12} .1 \mathrm{~g}$ of soil samples were placed in centrifugation tubes and added $30 \mathrm{~mL}$ of $0.1 \mathrm{~mol} \mathrm{~L}^{-1} \mathrm{of} \mathrm{BaCl}_{2}$ solution. The mixture is shaken for $60 \mathrm{~min}$ then centrifuged at $4,000 \mathrm{rpm}$ for $10 \mathrm{~min}$. The supernatant is separated and the entire procedures are repeated 2 times. The procedure was continued by adding $30 \mathrm{~mL}$ of $\mathrm{BaCl}_{2} 0.0025 \mathrm{~mol} \mathrm{~L}^{-1}$ to the soil sample. The mixture was shaken for $24 \mathrm{~h}$ and centrifuged at $4,000 \mathrm{rpm}$ for $10 \mathrm{~min}$. Before proceeding to 
the next process, the centrifugation tube with the sample was weighed first. A total of $30 \mathrm{~mL}$ of $0.02 \mathrm{~mol}$ $\mathrm{L}^{-1} \mathrm{MgSO}_{4}$ solution was added to the soil sample and the mixture was shaken for $24 \mathrm{~h}$. The mass of centrifugation tubes and soil samples were weighed just before centrifugation. Centrifugation was carried out at a rate of 4,000 rpm for $10 \mathrm{~min}$. Furthermore, the supernatant of this process was measured with AAS to determine the concentration of $\mathrm{Mg}$ remaining in the supernatant. Data retrieval was repeated three times to calculate the standard deviation.

\section{Chromium Desorption Study of Concentration, Time and pH Variations}

At the concentration variation of $0.5 \mathrm{~g}$ of soil samples were poured into a polyethylene bottle with a 15 $\mathrm{mL}$ of citric acid, tartaric acid and oxalic acid with a concentration of $0 ; 0.2 ; 0.4 ; 0.6$, and $0.8 \mathrm{~mol} \mathrm{~L}^{-1}$, respectively. The mixture is shaken for $24 \mathrm{~h}$ which then separated the filtrate. The chromium concentration in the filtrate after the interaction was measured by the AAS instrument. Data retrieval is repeated three times to calculate the standard deviation. The study was carried out at a temperature of 27 ${ }^{\circ} \mathrm{C}$ and a pressure of $1 \mathrm{~atm}$. For $\mathrm{pH}$ and time variation were performed in the same way as concentration variation with the range of 3.5 to 8.5 for $\mathrm{pH}$ (adjusted by $\mathrm{HCl}$ and $\mathrm{NaOH}$ ) ${ }^{13}$; and $1-48 \mathrm{~h}$ for variation of times.

\section{Soil Analysis}

\section{RESULTS AND DISCUSSION}

This study aims to analyze soil samples (soil samples 1 and soil samples 2), which were taken from the area around the tannery leather waste stream. The analysis included analysis of total carbon content, cation exchange capacity (CEC) and analysis of chromium metal content in the soil, and also analyzed soil samples using FTIR and XRD. Analysis of soil samples with FTIR was performed to identify functional groups involved in the process of adsorption and desorption of heavy metals in the soil.

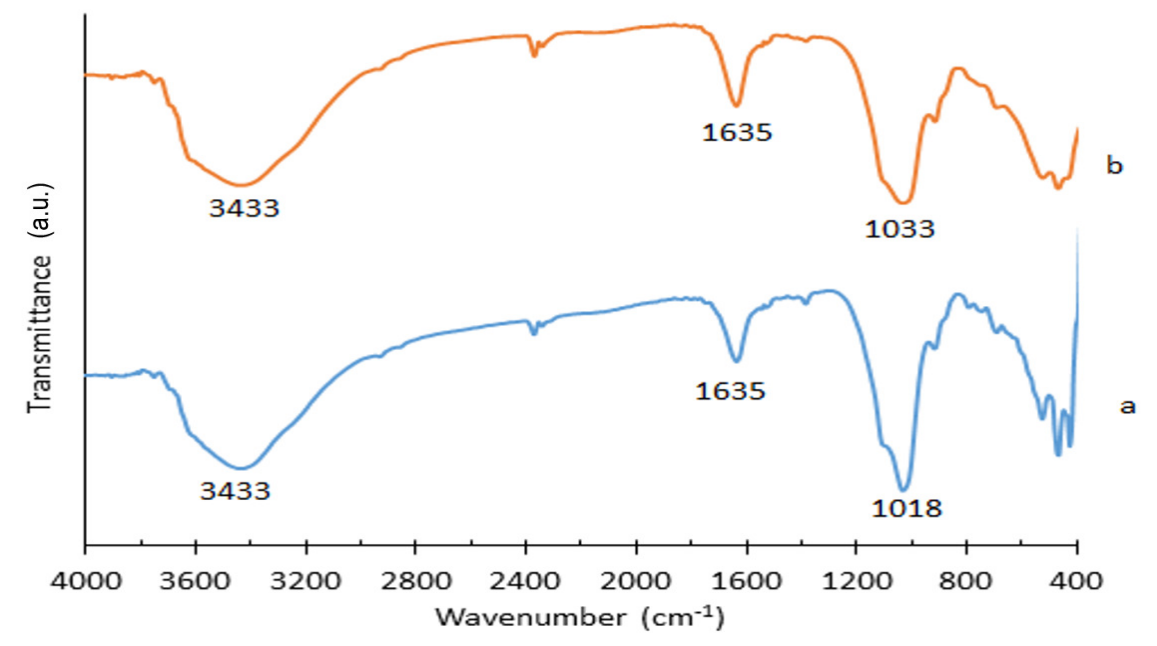

Fig.-1: FTIR Spectra of Soil Sample 1 (a) and Soil Sample (b)

Figure-1 showed that the FTIR spectra of both soil samples having an absorption pattern at relatively equal wave numbers. The wave number $3433 \mathrm{~cm}^{-1}$ in samples 1 and $3433 \mathrm{~cm}^{-1}$ in sample 2 shows the -OH group in the carboxylic acid. The wave numbers $1635 \mathrm{~cm}^{-1}$ in soil samples 1 and 2 showed the vibration of $\mathrm{O}-\mathrm{H}$ from silanol (Si-OH). Peak appearance at $1018 \mathrm{~cm}^{-1}$ in sample 1 and $1033 \mathrm{~cm}^{-1}$ in sample 2 showed vibrations of Si-O. In addition, at a wave number of $400-950 \mathrm{~cm}^{-1}$ revealed three absorption peaks. These three peaks appeared at $424 \mathrm{~cm}^{-1}, 462 \mathrm{~cm}^{-1}$, and $524 \mathrm{~cm}^{-1}$ possibly related to the absorption of the Si-O-Si bending vibration and the Si-O-Al bending vibration. From these IR spectra, it can be concluded that soil samples 1 and 2 contain many functional groups that play an important role in the bonding of metals in the soil.

Furthermore, soil samples were characterized by using XRD spectrometer which aimed to determine the type of mineral constituent contained in soil samples. Mineral content in soils, especially clay minerals, affect the presence of metal in the soil and the ability of soil to both adsorb and desorb of metal 
RASĀYAN J. Chem.

Vol. 12 | No. 3 |1279 - 1286| July - September | 2019

contamination. By comparing the diffractogram of both soil samples with standard data from Joint Committee on Powder Diffraction Standards (JCPDS) (quartz minerals, montmorillonite, and kaolinite), the type of mineral soil samples possible to be identified. The mineral components of the soil samples 1 and 2 are presented in Table-1 and 2. Based on the result of the diffractogram (supplementary data 1 and 2 ), it can be seen that the main components of the two soil samples are montmorillonite, kaolinite and quartz.

Table-1: Data Interpretation of XRD Analytical Results for Soil Sample 1

\begin{tabular}{c|c|c|c|c}
\hline No & $2 \Theta$ & $\mathrm{d}(\AA)$ & Intensity & Mineral \\
\hline 1 & 20,76 & 4,27 & 51 & quartz \\
\hline 2 & 19,83 & 4,47 & 39 & kaolinite \\
\hline 3 & 25,32 & 3,51 & 9 & montmorilonite \\
\hline 4 & 26,49 & 3,36 & 12 & montmorilonite \\
\hline 5 & 48,46 & 1,87 & 8 & montmorilonite \\
\hline 6 & 39,52 & 2,27 & 10 & montmorilonite \\
\hline 7 & 75,78 & 1,25 & 5 & quartz \\
\hline 8 & 79,98 & 1,19 & 5 & quartz \\
\hline 9 & 58,69 & 1,57 & 9 & kaolinite \\
\hline 10 & 55,62 & 1,65 & 11 & kaolinite \\
\hline 11 & 43,36 & 2,08 & 7 & kaolinite \\
\hline
\end{tabular}

Table-2: Data Interpretation of XRD Analytical Results for Soil Sample 2

\begin{tabular}{c|c|c|c|c}
\hline No & $2 \Theta$ & $\mathrm{d}(\AA)$ & Intensity & Mineral \\
\hline 1 & 43,92 & 2,05 & 68 & quartz \\
\hline 2 & 49,52 & 1,83 & 16 & quartz \\
\hline 3 & 26,87 & 3,31 & 8 & montmorilonite \\
\hline 4 & 48,24 & 1,88 & 8 & montmorilonite \\
\hline 5 & 35,64 & 2,51 & 8 & kaolinite \\
\hline 6 & 61,20 & 1,51 & 7 & kaolinite \\
\hline 7 & 45,63 & 1,98 & 8 & quartz \\
\hline 8 & 63,78 & 1,45 & 3 & quartz \\
\hline 9 & 54,69 & 1,67 & 7 & quartz \\
\hline 10 & 40,22 & 2,23 & 8 & quartz \\
\hline
\end{tabular}

From these data it can be seen that the soil sample 1 contains more clay minerals than sample 2 . The presence of clay minerals is also in accordance with the FTIR data analysis which showed the absorption of Si-O, Si-O-Si and Si-O-Al vibrations (Fig.-1). These clay minerals are capable to bind metal cations in the soil because they have a negative charge that can be stabilized by the cations in the interlayer part.

Table-3 below presented the results of soil analysis for total organic carbon, CEC and chromium content.

Table-3: Chromium Content, Total Organic Carbon, and CEC of Soil Sample 1 and 2

\begin{tabular}{c|c|c}
\hline Parameter & Soil sample 1 & Soil sample 2 \\
\hline Chromium content $\left(\mathrm{mg} \mathrm{kg}^{-1}\right)$ & $1402 \pm 47$ & $1071 \pm 62$ \\
\hline Total organic carbon/TOC $\left(\mathrm{mg} \mathrm{g}^{-1}\right)$ & $52.81 \pm 3.12$ & $50.11 \pm 1.78$ \\
\hline CEC $(\mathrm{cmol}+\mathrm{kg})$ & $16.72 \pm 0.84$ & $16.54 \pm 0.92$ \\
\hline
\end{tabular}

Note: chromium content taken $500 \mathrm{~m}$ from soil sample 2 is $155 \mathrm{mg} / \mathrm{kg}$

From Table-3 it can be discussed that the result of chromium content and TOC of soil sample 1 was higher than 2. Both soil samples were highly polluted by heavy metal with the closest position to the heavy metals point source affected the higher metal concentration in the samples. Considering that unpolluted soil sample taken about $500 \mathrm{~m}$ from the soil sample 2 position had the chromium content at $155 \mathrm{mg} \mathrm{kg}^{-1}$, indicating that the soil around tannery industry contained chromium up to 9 times from 
RASĀYAN J. Chem.

Vol. 12 | No. 3 |1279 - 1286| July - September | 2019

unpolluted soil. In another hand, CEC of soils is comparable. The higher chromium content of soil sample 1 possibly due to the position that closer than sample 2 from the tannery waste water outlet. High total organic carbon content indicated higher soil organic matter with various functional groups such as $\mathrm{COOH}$ and $-\mathrm{OH}$ which play a role in adsorbing and holding the metal ions. The higher soil organic matter content is generally followed by increases in cation exchange capacity and clay minerals existence. This clay mineral has the ability to bind metal cations in the soil.

\section{Chromium Desorption with a Variation of Organic Acid Concentration}

Metal desorption study was conducted by using the batch method. The desorption solution used is citric acid, tartaric acid and oxalic acid. The results of chromium desorption studies at various concentrations for soil samples 1 and 2 are shown in Fig.-2. The desorption results showed that the higher concentration of LMWOA produces a higher desorbed chromium until its optimum point. Increasing concentrations of desorption solution lead to an increasing number of organic acid molecules in the solution, thus more chromium could interact with the organic acid and causes the release of the metal from the soil.

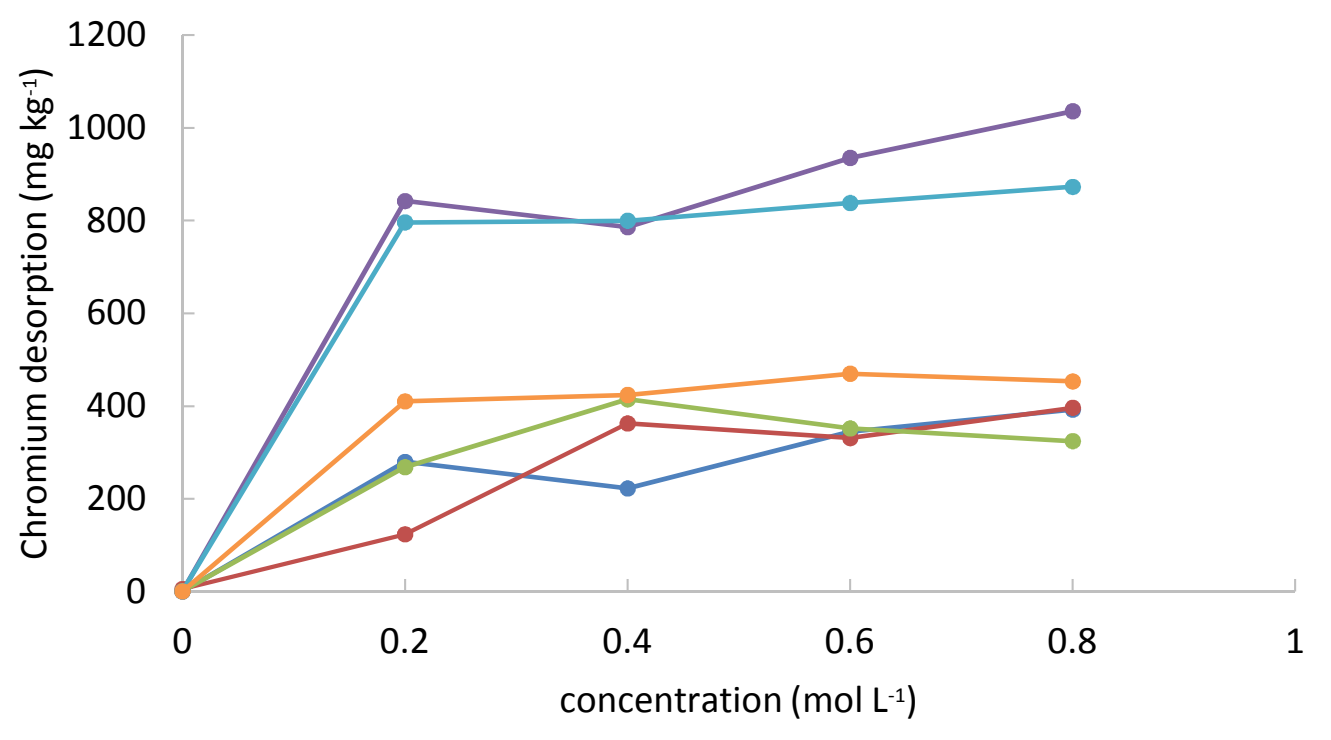

$$
\begin{aligned}
& \longrightarrow \text { Citric Acid in soil sample } 1 \\
& \longrightarrow \text { Oxalic Acid in soil sample } 1 \longrightarrow \text { Tartaric Acid in soil sample } 1 \\
& \longrightarrow \text { - Tartaric Acid in soil sample } 2 \longrightarrow \text { Oxalic Acid in soil sample } 2
\end{aligned}
$$

Fig.-2: Chromium Desorption of Organic Acid Concentration Variation in Soil Samples 1 and 2

When the influence of LMWOA on metal desorption from soil was compared to the desorption process in the absence of LMWOA (in neutral conditions at $\mathrm{pH}$ around 7), the chromium desorbed was only $5 \mathrm{mg}$ $\mathrm{kg}^{-1 .}$ In chromium desorption using citric acid solution, at concentrations of $0.8 \mathrm{~mol} \mathrm{~L}^{-1}$ from soil sample 1 could desorb $393 \mathrm{mg} \mathrm{kg}^{-1}$. Desorption of chromium by using tartaric acid at a concentration of $0.8 \mathrm{~mol} \mathrm{~L}^{-1}$ was able at $396 \mathrm{mg} \mathrm{kg}^{-1}$, while desorption using oxalic acid at a concentration of $0.6 \mathrm{~mol} \mathrm{~L}^{-1}$ produced chromium concentration at $352 \mathrm{mg} \mathrm{kg}^{-1}$.

In soil samples 2 the amount of chromium is preferably more desorbed than the soil sample 1 which the highest desorbed chromium at 1,038 by citric acid for $0.8 \mathrm{~mol} \mathrm{~L}^{-1}$. This condition due to soil samples 1 containing more clay miner so that the metal cations will be bonded stronger, thus it was difficult to desorb from the soil than sample 2. This result is consistent with Wuana and Okieimen ${ }^{14}$ which reported that metal content in the soil is correlated with the presence of clay minerals and the content of organic matter in the soil. The desorption results in soil samples 1 and 2 showed that citric acid has a higher chromium-desorption ability than other organic acids. The ability of organic acids in desorption of heavy metals of soil is influenced by the presence of carboxyl groups. 
RASĀYAN J. Chem.

Vol. 12 | No. 3 |1279 - 1286| July - September | 2019

Citric acid has the ability to desorb chromium higher than other acid compounds because citric acid has the most carboxyl group. Citric acid has three carboxyl groups, while tartaric acid and oxalic acid have two carboxyl groups. The results of this study are in accordance with the description of Ding et al. ${ }^{15}$ which stated that organic acids with more carboxyl groups have a higher ability in the desorption of heavy metals.

\section{Chromium Desorption with pH Variation}

The important parameter in the desorption process is the $\mathrm{pH}$ of the solution. The acidity of the solution affects the competitive abilities between $\mathrm{H}^{+}$ions and metal ions at the soil surface-active site.

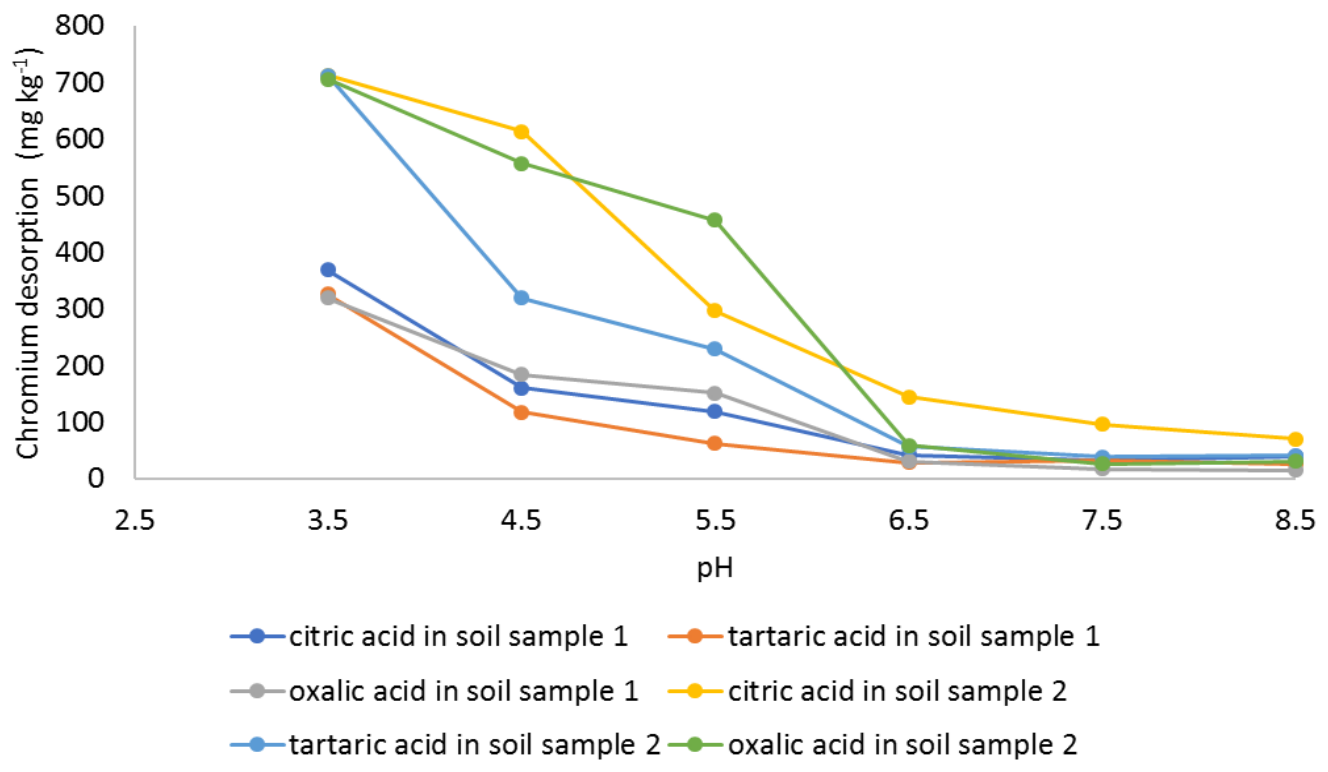

Fig.-3: Chromium Desorption in the presence of Organic Acid for pH Variation

Figure-3 described the results of chromium desorption in soil samples 1 and 2 of the three effective desorption solutions occurring at acidic $\mathrm{pH}$ (3.5). Desorption of chromium from polluted soil samples at $\mathrm{pH} 3.5$ in the absence of LMWOA was only $10 \mathrm{mg} \mathrm{kg}^{-1}$, while the presence of LMWOA produced chromium desorption $>700 \mathrm{mg} \mathrm{kg}^{-1}$. It means LMWOA significantly increase desorption of metal from polluted soil structure.

At a $\mathrm{pH}$ higher than 3.5 there is a reduction of desorbed chromium concentrations. Desorption occurs significantly from $\mathrm{pH}$ neutral to acidic condition, while at the basic solution it seems that desorption of metal was not significant. Metal desorption process effectively occurs in acidic $\mathrm{pH}$ due to the number of negative sites for cation adsorption decreased ${ }^{16}$. Also at the acidic solution, metal cations facing the competition with available permanent charged sites by $\mathrm{Al}^{3+}$ and $\mathrm{H}^{+}$, resulting in the release of chromium ions from the active site of the soil.

The high desorption of chromium at low $\mathrm{pH}$ is also due to $\mathrm{Cr}$ speciation in the soil due to the influence of $\mathrm{pH}$. Based on the chromium speciation, at $\mathrm{pH}$ 1-4 chromium cations in the soil are in the form of $\mathrm{Cr}^{3+}$, $\mathrm{Cr}^{6+}$ and $\mathrm{Cr}(\mathrm{OH})^{2+}$, whereas at $\mathrm{pH}$ 5-8 are in chromium hydroxide (solid phase). This results in desorption at low $\mathrm{pH}$ showing maximum yield due to the dominance of cation species that can bind to citric acid, tartaric acid, and oxalic acid species. At a $\mathrm{pH}$ above 5.5, desorption decreases as chromium has settled as chromium hydroxide and $\mathrm{Cr}(\mathrm{VI})$ in an anionic state.

Contact time is one of the important parameters in the desorption process. From Fig.-4, it is shown that the longer of desorption time will produce a higher concentration of metal. At the beginning of desorption time, the process progresses rapidly and continues to increase with time. This is possibly due to the number of active sites on organic acids that are available at first 5-10 min. The desorption results in soil samples 1 and 2 show that citric acid is capable to discharge chromium higher than tartaric acid and oxalic acid. 
Chromium desorption data with variations of the time were (Fig.-4) then used to calculate desorption kinetics by using Korsmeyer-Peppas model. The general assumption is that the possibility of metal ions to be desorbed from soil structure is comparable to the process of the drug release kinetics and their dissolution $^{17}$.

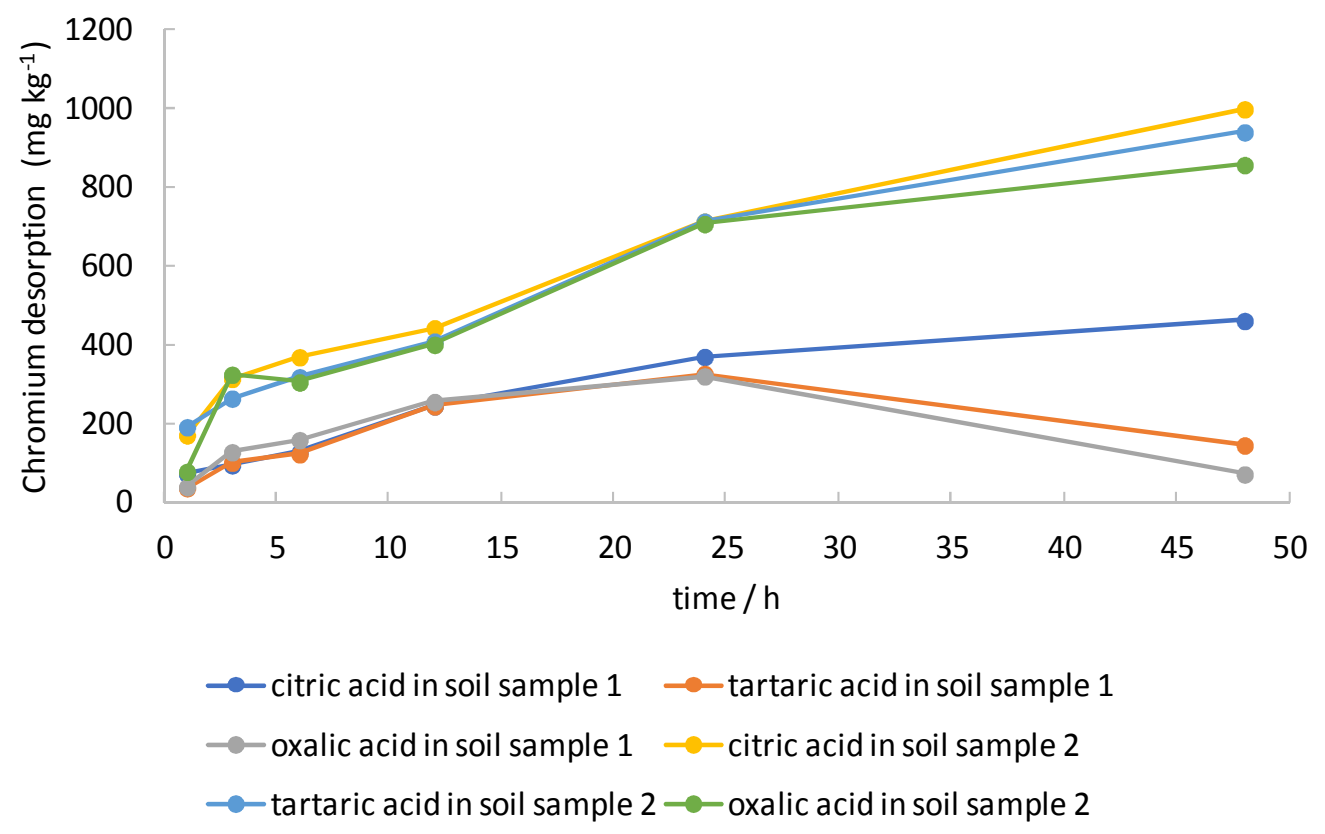

Fig.-4: Chromium Desorption in the presence of Organic Acid for Time Variation

The Korsmeyer-Peppas model can be described as:

$$
\mathrm{M}_{\mathrm{t}} / \mathrm{M}_{\infty}=\mathrm{k} \cdot \mathrm{t}^{\mathrm{n}} \rightarrow \log \left(\mathrm{M}_{\mathrm{t}} / \mathrm{M}_{\infty}\right)=\log \mathrm{k}+\mathrm{n} \log \mathrm{t}
$$

Where, $M_{t} / M_{\infty}$ is a fraction of desorbed metal ions at time $t$ with $M_{\infty}$ was $1402 \mathrm{mg} / \mathrm{kg}$ from the highest concentration of $\mathrm{Cr}$ in soil, $\mathrm{k}$ is desorption rate constant, and $\mathrm{n}$ is desorption exponent, respectively. From the graph plotting of function $\log \left(\mathrm{M}_{\mathrm{t}} / \mathrm{M}_{\infty}\right)$ vs $\log \mathrm{t}$, it was found that $\mathrm{k}$ values (from intersep) of $\mathrm{Cr}$ in the presence of LMWOA are 6,950 $\mathrm{min}^{-1}$ (citric acid), 4,298 $\mathrm{min}^{-1}$ (oxalic acid) and 5,525 $\mathrm{min}^{-1}$ (tartaric acid), respectively. Apparently, the capability of citric acid to desorb metal ions from the soil structure related to the higher desorption rate constant.

\section{CONCLUSION}

The result from chromium metal content analysis on soil sample 1 was $1,402 \mathrm{mg} \mathrm{kg}^{-1}$, while soil sample 2 was at $1,071 \mathrm{mg} \mathrm{kg}^{-1}$. Soil sample 1 has total organic carbon content and the CEC value higher than the soil sample 2. In the chromium desorption process, there is a tendency that the higher concentration of the desorption LMWOA solution produced higher of dissolved chromium metal. Desorption of soil samples by using citric acid, tartaric acid and oxalic acid are effectively achieved at acidic $\mathrm{pH}$. In addition, the higher metal ions desorbed from the soil structure in the presence of LMWOA related to the higher desorption rate constant $(\mathrm{k})$.

\section{ACKNOWLEDGEMENT}

Authors would like thanks to KEMENRISTEKDIKTI, the Republic of Indonesia for financially support this research through Penelitian Dasar Unggulan Perguruan Tinggi (PDUPT) 2018 (contract number: 81/UN1/DITLIT/DIT-LIT/LT/2018). The authors also thank Assoc. Prof. Toshikazu Kawaguchi (Hokkaido University-Japan) for input and comments that greatly improved the manuscript.

\section{REFERENCES}

1. A. Cassano, L. Della Pietra, E. Drioli, Ind. Eng. Chem. Res., 46(21), 6825(2007), DOI: 10.1021/ie070144n

2. D. Homa, E. Haile, A.P. Washe, Int. J. Anal. Chem., 2016, 7214932(2016), DOI: $10.1155 / 2016 / 7214932$ 
RASĀYAN J. Chem.

Vol. 12 | No. 3 |1279 - 1286| July - September | 2019

3. N. Shobha, B.M. Kalshetty, Rasayan. J. Chem., 10(1), 124(2017), DOI: 10.7324/RJC.2017.1011575

4. F.J. Stevenson, Humus Chemistry: Genesis, Composition, and Reactions, John Willey and Sons Inc., New York (1994).

5. S.A. Wasay, S.F. Barrington, S. Tokunaga, S. Prasher, J. Environ. Eng. Sci., 6, 611(2007), DOI: https://doi.org/10.1139/S07-004

6. Suherman, M. Kolb, C. Schimdt, D. Zachmann, M. Bahadir, Fresenius Environ. Bull., 22, 318(2013),

7. S. Yuan, Z. Xi, Y. Jiang, J. Wan, C. Wu, Z. Zheng, X. Lu, Chemosphere, 68(7), 1289(2007), DOI: 10.1016/j.chemosphere.2007.01.046

8. H. Jiang, T. Li, X. Han, X. Yang, Z. He, Environ. Monit. Assess., 184, 6325(2012), DOI: 10.1007/s10661-011-2422-y

9. M. Jalali, M. Taghipour, Chemosphere, 155, 395(2016), DOI: 10.1016/j.chemosphere.2016.04.063

10. P.N. Chiang, W. Wang, P. Huang, J.J. Wang, Appl. Radiat. Isot., 69, 844(2011), DOI: 10.1016/j.apradiso.2011.02.043

11. British Standard European Norm (BS EN) 13656 Characterization of Waste-Microwave Assisted Digestion with Hydrofluoric (HF), Nitric $\left(\mathrm{HNO}_{3}\right)$ and Hydrochloric $(\mathrm{HCl})$ Acid Mixture for Subsequent Determination of Elements, British Standards Institution, London (2002).

12. Deutsches Institut fur Normung (DIN ISO) 11260 Soil Quality: Determination of Effective Cation Exchange Capacity and Bulk Saturation Level Using Barium Chloride Solution, The German Institute for Standardization, Berlin (1997).

13. R. El Kaim Billah, Y. Elyamani, Y. Rakhila, M. Agunaou1, A. Soufiane, Rasayan. J. Chem., 12(1), 327(2019), DOI: $10.31788 /$ RJC.2019.1215078

14. R.A. Wuana, F.E. Okieimen, ISRN Ecology, 2011, 402647(2011), DOI: 10.5402/2011/402647

15. Y.Z. Ding, Z.G. Song, R.W. Feng, J.K. Guo, Int. J. Environ. Sci. Technol., 11, 33(2014), DOI: 10.1007/s13762-013-0433-7

16. Y.H. Rao, K. Ravindhranath, Rasayan. J. Chem., 10(4), 31104(2017), DOI: 10.7324/RJC.2017.1041829

17. S. Dash, P.N. Murthy, L. Nath, P. Chowdhury, Acta Pol. Pram.: Drug Research, 67(3), 217(2010), DOI: pubmed/20524422.

[RJC-5203/2019] 